УДК 341.3

DOI https://doi.org/10.32849/2663-5313/2020.5.61

Інна Роянова,

аспірантка кафедри права Свропейського Союзу

Національного юридичного університету імені Ярослава Мудрого

\title{
ICТОРІЯ СТАНОВЛЕННЯ ІНСТИТУТУ НЕЙТРАЛІЗОВАНИХ ТЕРИТОРІЙ УПРОДОВЖ ХІХ - НА ПОЧАТКУ ХХ СТОЛІТТЯ
}

Статтю присвячено становленню інституту нейтралізованих територій упродовж XIX - на початку XX cm. Зазначено, шо об'єкт дослідження має глибоке історичне коріння ще зі стародавніх часів. Однак ией період, як $і$ Середньовіччя, не досить досліджений, у зв'язку з чим автором статті було обрано пізній період Нового часу (XIX - поч. XX cm.), впродовж якого були укладені найбільш значущі міжнародні договори, що вплинули на становлення інституту нейтралізованих територій. Звертається увага на те, шо Віденський Конгрес 1815 р. став відправною точкою для розвитку і становлення інституту постійного нейтралітету. Як наслідок, у міжнародних договорах упродовж XIX cm. - на початку XX cm. (наприклад, Додатковий трактат про Краків 1815 р., Лондонський договір 1864 р., Карлстадська Конвениія 1905 р.) застосовували поняття «нейтралітет держави», наділяючи його ознаками, що притаманні інституту нейтралізованих територій. Водночас були такі угоди, аналіз яких указує на ознаки встановлення режиму нейтралізованих територій, втім у тексті безпосередньо не міститься вказівки ні на «нейтралітет держави», ні на «нейтралізовані території (Конвениія щодо проток Дарданельської і Босфорської 1856 р., Конвениія щодо утримання в Чорному морі військових судів 1856 р., Константинопольська конвениія 1888 р., Договір про Шпічберген 1920 р.). Звертається увага на те, що доктрина міжнародного права впродовж ХІХ периої половини XX ст. мала негативне ставлення до ототожнення понять «нейтралітет держави» та «нейтралізовані територї̈.. Однак деякі вчені иього періоду (А.-В. Гефтер, Л.Ф.Л. Опенгейм) розглядали нейтралітет частини територї як різновид постійного нейтралітету, шо можна, мабуть, вважати за аналогією нейтралізованими територіями. Наприкіниі автор статті робить висновок, що інститут нейтралізованих територій має певні властивості інституту постійного нейтралітету (наприклад, забороняється прохід уздовж иієї території іноземних військових формувань). Разом з тим ие режим, який діє під час війни в межах визначеної за домовленістю держав території. Водночас постійний нейтралітет є особливим статусом держави як суб'єкта міжнародного права, що діє як у мирний, так і у воєнний час.

Ключові слова: постійний нейтралітет, нейтралізовані території, нейтралітет частини території, нейтралізація, демілітаризація.

Постановка проблеми. У вітчизняній науці міжнародного права останніх років відсутні комплексні дослідження таких інститутів, як демілітаризовані та нейтралізовані території. Водночас історія міжнародного права свідчить про те, що вони з'явилися ще у стародавні часи. Цей період поки що залишається не досить дослідженим, у зв'язку 3 чим важко навести конкретні приклади про встановлення демілітаризованих чи нейтралізованих зон і з'ясувати ключові ознаки таких територій. Так, у наукових джерелах можна знайти згадку про прориття тунелю в Стародавньому Китаї у 8 ст. до н.е., який заборонялося використовувати у воєнних цілях [1, с. 268]. Також подібна ситуація має місце щодо періоду Середньовіччя. Більшість прикладів, коли держави укладали між собою договори про створення окремих територій (зон), у межах яких заборонялися будь-які воєнні дії, пов'язують уже з Новим часом. Але і вони поки що розглядаються в загальноісторичному аспекті без виокремлення найголовніших ознак цих інститутів. Однак ці феномени потребують детального вивчення, оскільки практика багатьох сучасних держав, в яких встановлено режими демілітарізованих та (або) нейтралізованих територій, підтвердила свою ефективність.

Відомим прикладом є територія Аландських островів, які в 1856 р. були демілітаризовані після підписання Конвенції про демілітаризацію Аландських островів [2], а згодом нейтралізовані в 1921 році [3]. Статус цієї території було підтверджено Паризьким мирним договором 3 Італією, Болгарією, Угорщиною, Румунією та Фінляндією 1947 р. [4]. Після Другої світової війни 
і дотепер Аландські острови залишаються територією, що має особливий статус за міжнародним правом (це передбачено Протоколом 2 до Угоди щодо приєднання Королівства Норвегія, Республіки Австрія, Республіки Фінляндія та Королівства Швеція до Європейського Союзу 1994 р. [5]). Незважаючи на те, що декілька разів їх намагалися ремілітаризувати під час Першої та Другої світових війн, вони зберегли свій статус і є прикладом історично сформованої демілітаризованої та нейтралізованої території. Таким чином, вживані заходи в межах цих зон сприяють примиренню держав у післявоєнний період і здатні гарантувати безпеку та збереження дружніх відносин між ними.

Ще слід звернути увагу на таку проблему, що в міжнародних договорах упродовж XIX ст. та на початку XX ст. ототожнювалися поняття «нейтралізовані території» «нейтралітет держави» або «нейтралітет частини території держави». Таким чином, ці поняття потребують уточнення.

Аналіз останніх досліджень і публікацій. Як зазначено було раніше, натепер відсутні праці, присвячені міжнародно-правовому статусу як демілітаризованих, так і нейтралізованих територій. Дещо інша ситуація спостерігається щодо інституту постійного нейтралітету, зокрема, окремі праці таких сучасних учених, як А.І. Дмітрієва, А.В. Кондакова, присвячені історії його виникнення, становлення, розвитку. Вивченням цих інститутів у загальних рисах займалися відомі юристи-міжнародники XIX ст. - першої половини XX ст., а саме: А.-В. Гефтер, В.Е. Грабар, В.П. Даневський, Ф.Ф. Мартенс, Б.Е. Нольде, Л.Ф.Л. Оппенгейм, А.Н. Стоянов, О.О. Таубе, Ч.Ч. Хайд. Уже в ХХ ст. дослідженням демілітаризованих та нейтралізованих територій, а також інституту постійного нейтралітету займалися вчені Б.м. Кліменко, О.І. Тіунов, Г.І. Тункін. Окремі праці Н.В. Дінь, Б.Р. Тузмухамедова присвячені концепції «зон миру». Вагомим є внесок Л.Д. Тімченка, який займався дослідженням правового регулювання демілітаризації та нейтралізації Архіпелагу Шпіцберген. Однак у вітчизняній науці проблема залишається не вирішеною, оскільки відсутні комплексні дослідження, які б розглядали не лише в загальних рисах інститути демілітаризованих та нейтралізованих територій, а й розкривали б особливості їхнього міжнародно-правового статусу.

Мета статті - дослідити, як формувався інститут нейтралізованих територій упродовж XIX ст. і на початку XX ст. та виокремити його головні ознаки. Предмет дослі- дження - найбільш значущі міжнародні договори, укладені впродовж цього періоду, якими було передбачено створення нейтралізованих територій (зон).

Виклад основного матеріалу. Вагомою подією XIX ст. був Віденський конгрес 1815 року, який вплинув на подальший розвиток міжнародного права загалом і його інститутів зокрема. Ним було започатковано інститут постійного нейтралітету, що пов'язано з визнанням постійного нейтралітету Швейцарії. Однак свої наміри щодо такої політики вона висловлювала ще задовго до Віденського конгресу. Так, протягом тридцятирічної війни (1618-1648рр.) Швейцарія підтримувала політику озброєного нейтралітету, тобто не брала участі у війні з іншими державами і займала неупереджене становище. Війна завершилась Вестфальським миром 1648 р., яким було визнано Швейцарію як незалежну державу (ст. 63 Мюнстерського договору 1648 р.) [1]. Уже на Віденському конгресі від 20 березня 1815 року було підписано Декларацію держав про справи Геветичного союзу, в якій визнавався постійний нейтралітет Швейцаpiї. Декларація була включена до Заключного акта Віденського конгресу від 9 червня 1815 р. у вигляді окремого додатка (Annex 11), а також їі положення було продубльовано у ст. 74-84 цієї угоди [2].

Крім того, 8(20) листопада представники Австрії, Великобританії, Франції, Росії, Пруссії та Португалії підписали Акт про визнання та гарантії постійного нейтралітету Швейцарії і недоторканості їі території [3]. Могутні держави того часу визнавали нейтралітет Швейцарії і гарантували його. Ця угода досі чинна, незважаючи на численні війни, які були після їі підписання. Надалі постійний нейтралітет Швейцарії було підтверджено статтею 435 Версальського мирного договору від 28 червня 1919 року [4]. Тоді гарантії нейтралітету Швейцарії визнали 30 країн-учасниць договору. Протягом Другої світової війни ця країна також зберегла свій статус. Таким чином, з визнанням статусу постійного нейтралітету Швейцарії в науці міжнародного права з'явився новий інститут.

Отже, у царині міжнародного права паралельно стали розвиватися інститут нейтралізованих територій та інститут постійного нейтралітету. Це вплинуло на правове регулювання зазначених інститутів і спричинило виникнення неузгодженостей у їхній регламентації.

Що стосується позиції доктрини міжнародного права щодо особливостей 
правового регулювання зазначених відносин упродовж XIX ст., то слід зазначити таке. Так, О.О. Таубе мав негативне ставлення до тотожного вживання понять «нейтралітет території» та «нейтралізовані території» у текстах міжнародних договорів. Вважав їх такими, що позначають різні правові інститути. Зокрема, на його думку, поняття «нейтралізація» потрібно розуміти як «вилучення зі сфери дії воєнного насилля, зі сфери війни загалом окремих осіб, предметів (матеріальних благ - рухомої чи нерухомої власності), відомих засобів боротьби, нарешті, місця боротьби, що поступово переходять у нейтралізацію самих суб'єктів права війни, незалежних держав. Усе це являє собою сучасне поняття «права війни» [10, с. 151-152].

Водночас «право нейтралітету являе собою сукупність норм, які визначають права і обов'язки держав - суб'єктів міжнародного права, що не беруть участь у війні» [10, с. 153-154]. Таким чином, учений розкриває суть нейтралізації як заходу, спрямованого на позбавлення можливості використовувати у воєнних цілях як окремих об'єктів, осіб, предметів, так і певних ділянок території держави. 3 цього можна зробити висновок, що нейтралізованими можуть бути лише певні частини території. Тоді видається неможливим, якщо режим нейтралізованої території стосується всієї держави, оскільки це ознака нейтралітету, який визначає їі правовий статус на міжнародній арені. Отже, поняття «нейтралітет території» та «нейтралізовані території мають різне значення.

Водночас потрібно звернути увагу на бачення іншими вченими XIX ст. інституту нейтралізованих територій через їхнє бачення інституту постійного нейтралітету. Так, професор А.-В. Гефтер розрізняв «повний або суворий нейтралітет» від «нейтралітету неповного», «нейтралітет цілої території» від «нейтралітету її частини» [11]. Можна припустити, що вчений під «нейтралітетом неповним» або «нейтралітетом частини території» мав на увазі нейтралізовані території. Таке бачення А.-В. Гефтера нагадує спробу ототожнити ці два поняття. Схожі погляди мав учений Л.Ф.Л. Опенгейм, який виокремлював частковий і загальний нейтралітет. Частковий, на його думку, полягає у можливості нейтралізації частини території держави (наприклад, нейтралізація островів Корфу і Паксос як територій, що належать Греції). Загальний нейтралітет є нейтралітетом держави загалом, «жодна частина території якої не оголошена нейтралізованою на підставі договору» [12, с. 194-195].

Водночас професор Ф.Ф. Мартенс мав негативне ставлення до таких видів нейтра- літету, як «повний» або «неповний», і вважав, що він «може бути лише абсолютним» $[13$, c. 604$]$.

Далі потрібно розглянути окремі приклади нейтралізованих територій упродовж XIX ст., щоб визначити головні ознаки, які відрізняють нейтралізовані зони від постійного нейтралітету.

Нейтралізована територія Кракова. Правове регулювання передбачено Додатковим трактатом про Краків, області його і конституції, що був укладений у Відні між Росією, Австрією і Пруссією 3 травня (21 квітня) 1815 р. (далі - Додатковий трактат про Краків) [14, с. 358]. Стаття 1 цього міжнародного договору встановлюе таке: «Місто Краків 3 належною йому областю буде завжди шануватися містом вільним, незалежним і абсолютно нейтральним під заступництвом трьох Високих Договірних Сторін». Ця норма також була продубльована у ст. 6 Заключного акта Віденського конгресу, підписаного 28 травня (9 червня) 1815 року [15]. Крім того, Додатковий трактат про Краків у ч. 1 ст. 6 передбачив, що «Договірні Сторони зобов'язуються поважати повсякчас і вимагати, щоб всіма поважався нейтралітет вільного міста Кракова та його області. Жодні військові сили ні в якому разі не можуть бути введені».

Хоча в тексті було застосовано поняття «нейтралітет», фактично йшлося про встановлення нейтралізованої території. Пояснити це твердження можна таким чином. Суверенітет цього державоподібного утворення було певним чином обмежено з боку Високих Договірних Сторін (Росія, Австрія, Пруссія). Так, ст. 7 Додаткового трактату Конституція вільного міста Кракова була ухвалена і їі дотримання гарантувалося ними. Крім того, в ст. 7 зазначається про призначення комісара у складі трьох представників від держав, які уповноважені були представляти Краків і втілювати положення його Конституції. Таким чином, вільне місто Краків було скоріше нейтралізованою територією.

Нейтралізація Іонічних островів. Правове регулювання здійснює Лондонський договір 1864 р. Ця територія перебувала під протекторатом Англії впродовж 1815-1864 років, але на підставі договору, що був підписаний на Лондонській конференції 1864 року (Лондонський договір) між Об'єднаним Королівством, Францією, Росією і Грецією, передбачено було передачу островів Корфу і Паксос Королівству Греція, яке на той момент уже мало статус нейтралітету. Ця угода в ст. 2 передбачала, що «острови Корфу і Паксос мають після свого об'єднання з Єлінським Королівством 
користуватися перевагами нейтралітету... Його Величність Король гарантує підтримання такого нейтралітету». Крім того, ст. 9 Лондонського договору 1864 р. містила зобов'язання, яке покладала на себе Великобританія, відкликати 3 території Іонічних островів воєнні сили Ї̈і Величності впродовж трьох місяців [16]. Насправді, в контексті цієї угоди йшлося про встановлення режиму нейтралізованої території островів Корфу і Паксос, але в тексті Лондонського договору 1864 р. це визначено як «користуватися перевагами нейтралітету».

Нейтралізація Чорного моря. Правове регулювання передбачає Паризький договір 1856 р., який завершив Кримську війну 1853-1856 рр. і оголосив Чорне море нейтральним, що було передбачено статтями XIXIII. Море було відкрито для торговельного мореплавства, але заборонявся вхід воєнним суднам у його води і в порти як прибережних держав, так і всіх інших (ст. XI) [17]. Крім того, Конвенція між Росією і Туреччиною щодо утримання в Чорному морі військових судів 18 (30) березня 1856 у ст. ст. 1 та 2 передбачила, що «Високі договірні сторони взаємно зобов'язуються не мати в Чорному морі інших військових судів, крім тих, яких число, сила і розміри визначені... Високі Договірні Сторони надають собі право утримувати кожна по шість у зазначеному морі парових судів 50 метрів довжини по ватерлінії, місткістю не більше 800 тонн, і по чотири легкі парові або вітрильні судна, місткість яких не повинна перевищувати 200 тонн у кожному» [18, с. 329-330]. Однак Конвенція між Росією і Туреччиною від 1 (13) березня 1871 року у ст. 1 встановила, що «Конвенція між Росією і Туреччиною щодо утримання в Чорному морі військових судів назавжди скасовується» [18, с. 505].

Нейтралізація проток Дарданельської і Босфорської. Правове регулювання здійснює Конвенція щодо проток Дарданельської і Босфорської від 18 (30) березня 1856, де в ст. 1 Конвенція передбачила «... завжди було заборонено військовим судам Держав іноземних входити в протоки Дарданелли i Босфор i, що доки Порта буде знаходитися в світі, Иого Величність не допустить ніякого іноземного військового судна в зазначені протоки» [18, с. 327].

Проте у березні 1 (13) 1871 р. у Лондоні був підписаний Трактат про перегляд Паризького мирного трактату від 18 (30) березня 1856 року. Ним у ст. 1 було встановлено таке: «Статті XI, XIII XIV Паризького трактату від 30 березня 1856 року, так само спеціальна конвенція, укладена між Блискучою Портою і Росією...скасовуються і замінюються наступ- ною статтею». Далі ст. 2 передбачає «закриття Дарданельської і Босфорської проток, як воно було встановлено конвенцією 30 березня 1856 р., зберігає свою силу, з правом відкривати вказані протоки в мирний час для військових судів дружніх і союзних держав у тому випадку, коли Блискуча Порта знайде це необхідним для забезпечення виконання постанов Паризького трактату від 30 березня 1856 року» [18, с. 499]. Таким чином, як Конвенція щодо проток Дарданельської і Босфорської від 18 (30) березня 1856, так і Трактат від 1 (13) березня 1871 р. про перегляд Паризького мирного трактату від 18 (30) березня 1856 року безпосередньо не вказують, що передбачені цими угодами та втілені заходи визначені поняттям «нейтралізовані території», однак зміст статей таких міжнародних договорів підтверджує встановлення режиму нейтралізованих територій у межах цих просторів.

Нейтралізація Суецького каналу була передбачена Константинопольською конвенцією 1888 року. Ця угода теж безпосередньо не містила вказівок про нейтралізацію цього каналу, проте 3 аналізу змісту статей Конвенції сторони погодилися вжити заходи, що за своєю суттю вважаються нейтралізацією Суецького каналу. Так, ст. 4 передбачено таку заборону: «...жодні дії, що дозволяються під час війни, ворожі чи такі, що мають на меті порушення вільного плавання вздовж Каналу, не будуть допущені в Каналі і в його вхідних портах, так само як і в межах трьох морських миль від цих портів...» [19].

Нейтралізована зона між Норвегією та Швецією. Конвенція щодо встановлення нейтральної зони і знищення фортифікаційних споруд (Карлстадська Конвенція) підписана у Стокгольмі 26 жовтня 1905 року. У ст. 1 зазначено, що: «Задля забезпечення мирних відносин між двома Державами повинна бути встановлена з обох сторін спільного кордону територія (нейтральна зона), яка користується перевагами постійного нейтралітету». Частина 4 ст. 1 роз'яснює, що нейтралітет цієї території передбачає «заборону жодних воєнних операцій у межах цієї зони, заборону використовувати іiі як базу для воєнних операцій і зосереджувати збройні військові сили, окрім тих, що необхідні для збереження публічного порядку і для забезпечення підтримки в разі настання надзвичайних ситуацій». У контексту цієї угоди застосування терміна «нейтралітет теритоpiï» теж здійснюється у значенні поняття «нейтралізована територія» [20].

Нейтралізована територія архіпелагу Шпіцберген. Статус нейтралізованої території було передбачено у розробленому проєкті 
конвенції в Христианії (Осло) у 1910 р. на конференції трьох держав (Норвегія, Росія, Швеція). Загалом цей проєкт складався з 15 глав i 77 статей та був заснований на Угоді 1872 p. [21], що включала вимогу мирного характеру діяльності підданих і компаній на теритоpiï архіпелагу. Фактично це була дипломатична переписка у формі обміну нотами між Росією і Швецією-Норвегією 1871-1872 рр., яка отримала назву Угода 1872 р. [22, с. 19]. Її положення містили в собі ідею нейтралізації Шпіцбергену в майбутньому. Стаття 3 проєкту Конвенції 1910 р. передбачала, що «Шпіцберген буде завжди розглядатися як нейтральна територія» [22, с. 26-27]. Хоча йшлося про нейтралізацію території архіпелагу.

Термін «нейтральний», як зазначає вчений Л.Д. Тімченко, застосовувався в дипломатичній практиці щодо шпіцбергенського питання в двох значеннях: «1) для визначення приналежності архіпелагу будь-якій державі; 2) для позначення режиму демілітаризації та нейтралізації Шпіцбергену» [22, с. 27]. Вже після Першої світової війни було підписано на Паризькій конференції Договір про Шпіцберген (Свальбард) 9 лютого 1920 року, що передбачив у ст. 9 таке: «Норвегія бере на себе зобов'язання не створювати та не допускати створення жодних морських баз у місцевостях, вказаних у статті 1, і не будувати жодних укріплень у вказаних місцевостях, які ніколи не повинні бути використані у воєнних цілях» [23]. Таким чином, Договір 1920 р. регламентуе режим нейтралізованої території архіпелагу Шпіцберген.

Таким чином, упродовж XIX ст. та на початку XX ст. поняття «нейтралітет» застосовувалося у текстах найбільш значущих міжнародних договорів у значенні поняття «нейтралізовані території». Це можна пояснити таким чином. У ці часи була загальноприйнятою і як доказ закріпленою на міжнародно-договірному рівні певна специфічна термінологія. Остання у післявоєнний період під впливом Паризької мирної конференції 1919 р. зазнала суттєвих змін, що, зрештою, вплинуло на подальше застосування цих понять у контексті міждержавних угод. Якщо до Першої світової війни поняття «нейтралізовані території» означало заходи, які зараз пов'язують з режимом демілітаризованих територій, то у післявоєнний період наука міжнародного права почала розглядати ці поняття як такі, що мають різне значення, хоча і схожі між собою.

\section{Висновки}

На підставі вищезазначеного можна сформулювати такі висновки:

1. Інститут нейтралізованих територій $€$ одним із найдавніших у міжнародному праві. Однак період стародавніх часів залишається поки що не досить дослідженим, як і період Середньовіччя. Обрання в межах цієї статті періоду XIX ст. - початку XX ст. пояснюється тим, що впродовж цього часу були укладені найбільш значущі міжнародні договори, що вплинули на подальший розвиток інституту нейтралізованих територій. Їх аналіз дає змогу визначити головні ознаки нейтралізованих територій:

а) це певний простір, що має окреслені на місцевості межі, який заборонено використовувати як театр війни (воєнних дій);

б) цей інститут має певні властивості інституту постійного нейтралітету (наприклад, забороняється прохід уздовж цієї території іноземних військових формувань);

в) це режим, який діє під час війни в межах території, визначеної за домовленістю держав. Водночас постійний нейтралітет є особливим статусом держави як суб'єкта міжнародного права, що діє як у мирний, так і у воєнний час. Також він полягає у неучасті у всіх війнах, які можуть виникнути у майбутньому.

2. Практика держав упродовж XIX ст. та на початку XX ст. в укладенні міжнародних договорів щодо врегулювання цих відносин засвідчила той факт, що більшість 3 розглянутих угод застосовували поняття «нейтралітет» для позначення режиму нейтралізованих територій (зокрема, Додатковим трактатом про Краків 1815 р., Лондонським договором 1864 р., Карлстадською Конвенцією 1905 р. та ін.). Були й такі міжнародні договори, які безпосередньо не використовують ці поняття, однак іх зміст підтверджує встановлення такого режиму в межах цих просторів (Конвенція щодо проток Дарданельської і Босфорської 1856 р., Конвенція щодо утримання в Чорному морі військових судів 1856 р., Константинопольська конвенція 1888 р., Договір про Шпіцберген 1920 р.). Це можна охарактеризувати як притаманну цьому періоду міжнародну договірну практику щодо регламентації зазначених відносин.

\section{Список використаних джерел:}

1. Буткевич О.В. Міжнародне право Стародавнього Світу : підручник. Київ : Україна, 2004. 864 c. C. 268.

2. Convention on the demilitarization of the land Islands. Paris, 30 March 1856 (translation from the original french text). URL: http://www. kulturstiftelsen.ax/images/internationellaavtal/ engelskaavtal.pdf. (дата звернення: 11.04.2020).

3. Convention relating to the Non-Fortification and Neutralisation of the Aaland Islands. Geneva, 20 October 1921. Treaty Series, League 
of Nations. Vol. 9, p. 211-221. URL: https:// treaties.un.org/doc/Publication/UNTS/LON/ Volume\%209/v9.pdf. (дата звернення: 11.04.2020).

4. Treaties of Peace with Italy, Bulgaria, Hungary, Roumania and Finland. Paris, 10 February 1947. URL: https://babel.hathitrust.org/cgi/pt? $\mathrm{d}=$ osu.32435066406612;view=1up;seq=231. $\quad$ (дата звернення: 11.04.2020)

5. Treaty concerning the accession of the Kingdom of Norway, the Republic of Austria, the Republic of Finland and the Kingdom of Sweden to the European Union, 1994. URL: https://eur-lex. europa.eu/eli/treaty/acc_1994/act_1/ pro_2/sign. (дата звернення: 11.04.2020).

6. Peace of Westphalia 1648 (Peace Treaty between the Holy Roman Emperor and the King of France and their respective Allies May 15, 1648) URL: https://avalon.law.yale.edu/17th_century/ westphal.asp. (дата звернення: 11.04.2020).

7. Acte du congrès de Vienne du 9 juin 1815 avec ses annexes. British and foreign state papers 1815-1816, vol. 3 (compiled by the Librarian and Keeper of the papers, Foreign Office). URL: https:// books.google.co.uk/books?id =UY8AAAAAYAAJ\& $\mathrm{pg}=\mathrm{PA} 7 \& \mathrm{hl}=\mathrm{ru} \# \mathrm{v}=$ onepage \&q\&f=false. (дата звернення: 11.04.2020).

8. Акт относительно признания и гарантии постоянного нейтралитета Швейцарии и неприкосновенности ее территории от 8(20) ноября 1815 года. Действующее международное право. Москва : Московский независимый институт международного права. Т. 1. 1996.

9. The Versailles Treaty June 28, 1919: Part XV URL: https://avalon.law.yale.edu/imt/partxv.asp. (дата звернення: 11.04.2020).

10. Таубе М.А. История зарождения современного международного права. (Средние века). Т. 2. Часть особенная. Принципы мира и права в международных столкновениях средних веков. Харьков : Паровая Тип. и Литогр. Зильберберг, 1899. 361 c.

11. Гефтер А.В. Европейское международное право : монография / пер. К. Таубе. СанктПетербург : Тип. В. Безобразова и Комп., 1880. $572 \mathrm{c}$.

12. Оппенгейм Л. Международное право. Том 2. Война. Нейтралитет. / Под ред. С.А. Голунский. Москва : Изд-во иностр. лит., 1950. 498 с.
13. Мартенс Ф.Ф. Современное международное право цивилизованных народов. Т. 2. 5-е изд., испр. и доп. Санкт-Петербург : Тип. А. Бенке, 1905.626 с

14. Мартенс, Ф. Собрание Трактатов и Конвенций, заключенных Россиею с иностранными державами. Т. 3 : Трактаты с Австрией 1808-1815 г. Санкт-Петербург : Тип. А. Бенке, 1876.550 c.

15. Acte du congrès de Vienne du 9 juin 1815 avec ses annexes British and foreign state papers. 1815-1816, vol. 3 (compiled by the Librarian and Keeper of the papers, Foreign Office). URL:https:// books.google.co.uk/books?id= UY8AAAAAYAAJ\& $\mathrm{pg}=\mathrm{PA} 7 \& \mathrm{hl}=\mathrm{ru} \#_{\mathrm{v}}=$ onepage \&q\&f=false. (дата звернення: 11.04.2020).

16. Treaty of London March 29, 1864. URL: http://www.mfa.gr/images/docs/diethneis symvaseis/1864 london treaty.doc. (дата звернення: 11.04.2020).

17. Treaty of Paris March 30, 1856. URL: https://content.ecf.org.il/files/M 00934 TreatyOfParis1856English.pdf. (дата звернення: 11.04.2020).

18. Мартенс Ф. Собрание Трактатов и Конвенций, заключенных Россией с иностранными державами Т. 15 : Трактаты с Францией 1822-1906. Санкт-Петербург : Тип. А. Бенке, 1909. 836 с.

19. Constantinople Convention October 29, 1888. URL: https://loveman.sdsu.edu/docs/1888C onstantinopleConventionon.pdf. (дата звернення: 11.04.2020).

20. Convention between Norway and Sweden relative to the establishment of a neutral zone October 26, 1905 (reproduced by the Secretariat for the Commission). UNCCP working paper (in French). URL: https://www.un.org/unispal/document/autoinsert-211915/. (дата звернення: 11.04.2020).

21. Дипломатическая переписка. Шпицберген 1871-1912. Санкт-Петербург : Типография В.Ф. Киршбаума, 1912. 83 с. (Известия Министерства Иностранных Дел. Приложение к кн. III, 1912).

22. Тимченко Л.Д. Шпицберген: История и современность (международно-правовой аспект). Харьков : Основа, 1992. 128 с. С. 19

23. Svalbard Treaty February 9, 1920. URL: https://app.uio.no/ub/ujur/oversatte-lover/ data/lov-19250717-011-eng.pdf. (дата звернення: 11.04.2020).

The article is devoted to the establishment of the institute of meutralized territories during the XIX early XX century. It is established that the object of study has a deep historical roots since ancient times. However, this period, like the Middle Ages, remains under-researched, that is why the author of the article chose the second half of the New Age period (XIX - early XX centuries), during which the most significant international treaties were concluded that influenced the formation the institute of neutralized territories. Attention is drawn to the fact that the Congress of Vienna in 1815 became the starting point for its development and for the institution of permanent neutrality. As a consequence, in international treaties during the XIX - early XX century applied the concept of "neutrality of the state", giving it the features of the concept of "neutralized territories". Such international treaties are, for example, the Cracow Additional Treatise of 1815, the Treaty of London of 1864, the Karlstad Convention of 1905. At the same time, there were such agreements, the analysis of which indicates the signs of establishing a regime of neutralized territories, however, the text does not directly refer to either "state neutrality" or "neutralized territories" (Convention on the straits of the Dardanelles and the Bosphorus 1856, the Convention on the Detention of Military Courts in 
the Black Sea 1856, the Constantinople Convention of 1888, the Svalbard Treaty of 1920). Attention is drawn to the fact that the doctrine of international law during the XIX - early XX century had a negative attitude towards the identification of the concepts of "state neutrality" and "neutralized territories". However, some scholars of this period (A.-V. Gefter, L.F.L. Oppenheim) considered the neutrality of part of the territory as a kind of permanent neutrality, which could probably be regarded by analogy as neutralized territories. In the end, the author concludes that the institute of neutralized territory has certain characteristics of the institute of permanent neutrality (for example, the passage along this territory of foreign military formations is prohibited). At the same time, it is a regime that operates during a war within the territory designated by agreement. Whereas permanent neutrality is a special status of the state as a subject of international law, which operates both in peacetime and in wartime.

Key words: permanent neutrality, neutralized territories, neutrality of part of the territory, neutralization, demilitarization. 